\title{
Arctic charr (Salvelinus alpinus) squeezed in a complex fish community dominated by perch (Perca fluviatilis)
}

\author{
Odd Terje Sandlund', Eivind Haugerud', Sigurd Rognerud ${ }^{3}$ and Reidar Borgstrom ${ }^{2}$
}

Sandlund OT, Haugerud E, Rognerud S and Borgstrøm R. 2013. Arctic charr (Salvelinus alpinus) squeezed in a complex fish community dominated by perch (Perca fluviatilis). Fauna norvegica 33: 1-11.

In the complex fish community of Lake Skasen, southeastern Norway, the relative population density, habitat use and diet of Arctic charr, perch, roach and burbot was studied by a gill net survey during June-September 2010. A marked segregation in habitat use was observed, with Arctic charr and burbot captured in the profundal and deepest part of the pelagic habitat, and perch and roach captured in the littoral and upper part of the pelagic. Perch dominated the total catches, followed by roach. Arctic charr occurred in low numbers in the catches, and also had a low annual growth rate. Even in June, at low water temperatures, Arctic charr were confined to the profundal. Both Arctic charr, roach and perch fed on the same cladocerans, but all size groups of perch had fish as an important part of the diet. Analysis of stable carbon and nitrogen isotopes revealed a narrow trophic niche of Arctic charr, positioned at the extreme pelagic end of the carbon gradient relative to the other fish species. These had a wider span of $\delta^{13} \mathrm{C}$ signatures, but more positioned towards the littoral end of the carbon gradient. The low growth rate of Arctic charr, despite a low population density, indicates that food is a limiting resource for charr in this lake, probably due to a confinement to the profundal habitat as a result of competition and predator avoidance. Since all age-classes of Arctic charr seem to be enclosed in the profundal habitat, intraspecific competition and predation may be supplementary stressors resulting in low annual recruitment and low population density, as well as low individual growth rate, i.e. the population is squeezed. The narrow trophic niche of Arctic charr compared to perch, roach and burbot, revealed by stable isostope analysis, supports this conclusion.

doi: 10.5324/fn.v33i0.1579. Received: 2013-01-07. Accepted: 2013-05-31. Published online: 2013-12-20.

Keywords: Trophic niche, Arctic charr, complex fish community, competition, predation

1 Norwegian Institute for Nature Research (NINA), P.O. Box 5685, NO-7485 Trondheim, Norway

2 Department of Ecology and Natural Resource Management, Norwegian University of Life Sciences, NO-1432 As, Norway

3 Norwegian Institute for Water Research (NIVA), Sandvikavegen 59, NO-2312 Ottestad, Norway

Corresponding author: Odd Terje Sandlund

E-mail: e-mail: ots@nina.no

\section{INTRODUCTION}

Arctic charr (Salvelinus alpinus (L., 1758)), typically inhabit cold, oligotrophic lakes with few fish species (Klemetsen et al. 2003), and is frequently the only fish species in many northern and alpine lakes (Klemetsen et al. 2003). The natural distribution of Arctic charr in Norway is mainly in lowland lakes along the coast, but also in inland lakes in the middle and northern part of the country (Huitfeldt-Kaas 1918; Hesthagen \&
Sandlund 1995). Indications are that climate warming, in general resulting in higher water temperatures, may put Arctic charr at a disadvantage relative to sympatric fish species (Finstad et al. 2011, Ulvan et al. 2011). The Arctic charr populations in lowland South Eastern Norway and southern Sweden are on the margin of the species' distribution in Scandinavia, and in many cases serious population decline and even local extinctions have been reported (Dickson 1975; Nysæther 1977; Sandlund et al. 2010). 
Several reasons have been suggested for the decline, such as increased agricultural and urban runoff, acid precipitation, introduced non-native species, and climate warming. Many of the marginal charr populations inhabit lakes with relatively complex fish communities (Huitfeldt-Kaas 1918), often with large populations of whitefish (Coregonus lavaretus (L., 1758)), perch (Perca fluviatilis L., 1758), and roach (Rutilus rutilus (L., 1758)) (Pethon 2005). It has repeatedly been demonstrated that Arctic charr declines when whitefish is introduced (Svärdson 1976; Museth et al. 2007; Sandlund et al. 2013), but still whitefish and Arctic charr may coexist in deep lakes in Scandinavia (Sandlund et al. 2010), and in many northern Canadian lakes (e.g. Johnson 1976). Perch and roach are probably also strong competitors with Arctic charr, both being effective zooplankton predators, and able to utilize both littoral and pelagic habitats (Winfield 1986; Winfield et al. 2008). Piscivorous fish like large perch, pike (Esox lucius L., 1758) and burbot (Lota lota L., 1758) affect the habitat use of potential prey fish, such as small Arctic charr (Brabrand \& Faafeng 1993; Langeland et al. 1995). In deep lakes, Arctic charr may find a refugium in the profundal region, but will still face competition from other cold water species, including whitefish and burbot (Knudsen et al. 2010). In shallow lakes, the cold water refugium in the profundal zone is missing, and Arctic charr must endure high summer temperatures, heavy predation and fierce competition.

Given this background, we would expect that in lakes with a diverse fish community, there is a break-even point regarding the size of the deepwater refugium required for Arctic charr to persist. Lake Skasen in South Eastern Norway, with a complex fish community consisting of perch, pike, roach, Arctic charr, brown trout (Salmo trutta L., 1758), European minnow (Phoxinus phoxinus (L., 1758)) and burbot (Brabrand \& Saltveit 1983), may be a lake close to this break-even point. The lake has a moderate maximum depth of $50 \mathrm{~m}$, and according to local fishermen the fishing effort has been substantially reduced during the last decades (J. Gressberg and J. Torgersrud, pers. comm.). The ecology of Arctic charr in coexistence with perch and roach has rarely been investigated in Norway, although knowledge about this relationship may be essential in order to manage these fish communities to conserve and protect threatened Arctic charr populations on the margin of the main distribution area of the species in Scandinavia (cf. Dickson et al. 1975, SLU 2012). To understand the processes associated with the decline and potential extinction of Arctic charr populations in southern Scandinavia, we investigated the fish community in Lake Skasen, where we expect that Arctic charr density will be low, with restricted habitat use and low individual growth rates.

\section{MATERIAL AND METHODS}

\section{Lake Skasen}

Lake Skasen is situated in Hedmark County, $266 \mathrm{~m}$ a.s.l. (Figure 1). The lake area is $13.35 \mathrm{~km}^{2}$, with maximum depth about $50 \mathrm{~m}$.
The catchment area is relatively small; around $64.5 \mathrm{~km}^{2}$ (Moen 1963), and is mostly forested, with Scots pine (Pinus silvestris L.) and Norwegian spruce (Picea abies (L.)). The climate in this area is characterized by cold winters and relatively warm summers. The lake is usually ice-covered from December to April-May. At the nearest meteorological station presently in operation (meteorological station 5600 Kongsvinger), the mean temperature is $-7.7^{\circ} \mathrm{C}$ in January, and $15.3^{\circ} \mathrm{C}$ in July. The trend in mean air temperatures for June-August from 1942 to 2004 (the period of operation for meteorological station 5650 Vinger, www.met.no) was slightly, but not significantly, negative $\left(\mathrm{R}^{2}\right.$ $=0.0066$ ).

The lake is oligotrophic, with a moderate humic content (water colour measured in 1988 at $12 \mathrm{mg} \mathrm{Pt} \mathrm{L}^{-1}$; S. Rognerud, unpublished data). During the 1980s, $\mathrm{pH}$ was measured just barely below 6 (Rognerud 1985, unpublished data). In spite of being assessed as having very good water quality in 1985 (Løvik 2001), the lake was limed from 1994 to 2009. During 2010, Secchi depth varied between 4 and $6 \mathrm{~m}$, with water colour yellowish brown in June, and greenish yellow in late summer and autumn. Water temperatures were measured through the summer of 2010, at 1, 2, 5, 10 and $20 \mathrm{~m}$ depth in the pelagic part, by use of Hobo temperature loggers. The lake is stratified, with a warm top layer from July to August (Figure 1). In 2010, water temperatures at $2 \mathrm{~m}$ depth were above $15^{\circ} \mathrm{C}$ from late June to early September.

Historically, most fish species in Lake Skasen were actively fished (J. Gressberg, pers. comm.). After 1950, the subsistence fishery for species like perch and roach declined, while Arctic charr were fished in considerable number at the spawning sites until the 1970s. Subsequently, even fishing for charr has declined substantially, and present exploitation is largely restricted to some angling for perch and pike, and a very

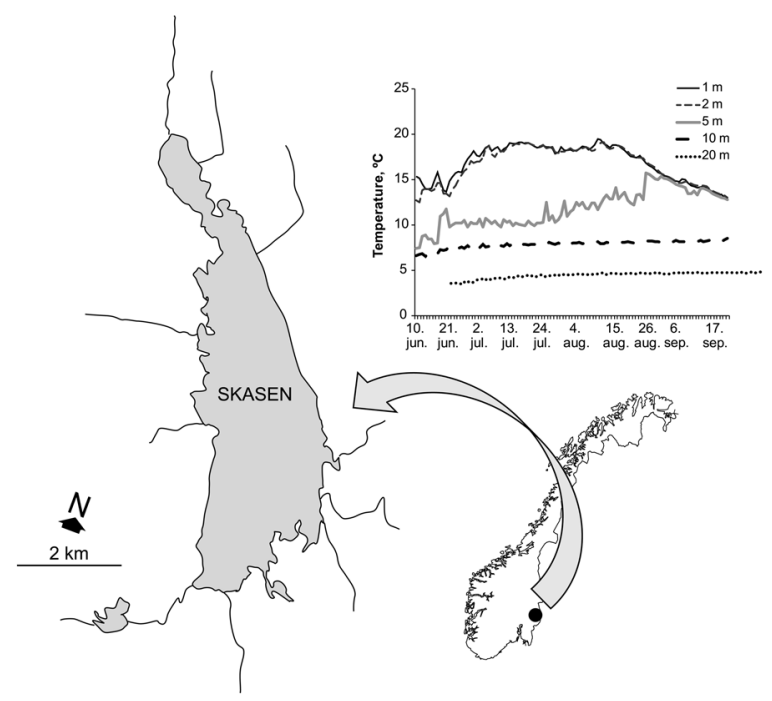

Figure I. The location of Lake Skasen (outlet UTM32 coordinates: $6695679 \mathrm{~N} ; 683288 \mathrm{E}$ ) and the water temperatures logged at various depths from 10 June to 17 September, 2010. 
restricted gillnetting in the autumn at a few Arctic charr spawning sites. In general, the present fishing pressure is probably very low for all species in the lake.

\section{Fish sampling}

Fish were sampled by fleets of monofilament gill nets, set both in the littoral, pelagic and profundal habitats, in June, July, August and September 2010. The ordinary littoral and profundal gill nets were $25 \mathrm{~m}$ in length, and $1.5 \mathrm{~m}$ in height, while the pelagic nets were $25 \mathrm{~m}$ long and $6 \mathrm{~m}$ in height, both types with the following mesh sizes: 10; 12.5; 16; 19; 21; 35 and $45 \mathrm{~mm}$ (bar mesh). In the littoral habitat, gill nets were set on the bottom at depths between 1 and $10 \mathrm{~m}$, while in the profundal habitat they were set on the bottom between 15 and $50 \mathrm{~m}$. The pelagic nets were set between 1-7 $\mathrm{m}$ and 10-16 m from the surface. All nets were set in the evening, between 1800 and $1900 \mathrm{hrs}$, and lifted between 0800 and 0900 hrs. In each sampling month, gillnetting lasted 3-4 nights. Catch per unit effort (CPUE) was defined as number of fish captured per $100 \mathrm{~m}^{2}$ standard gill net area per night. The gill net positions were recorded with a hand held GPS (Garmin GPSmap 60CSx) to ensure fishing on the same locality each month. Due to strong winds, the sampling in July could not be fully completed. Consequently, data on habitat use are not available for this month. Additional fishing for Arctic charr was performed with 19 and $21 \mathrm{~mm}$ mesh gill nets at the spawning grounds in October, with the assistance of local fishermen. The charr spawning grounds in this lake are located in the littoral zone, at $0.5-2 \mathrm{~m}$ depth.

Fish total length was measured (in $\mathrm{mm}$ ) and weighed (to nearest $0.1 \mathrm{~g}$ ) on a digital balance. Sex and sexual stage was determined according to Dahl (1917). For age determination, otoliths were sampled from perch, Arctic charr and burbot, and opercular bones were sampled from roach. Stomach contents were sampled from Arctic charr, perch, roach and burbot. The otoliths from Arctic charr and perch were cut through the nucleus and burnt before reading the winter zones under a binocular microscope (Christensen 1964; Power 1978). The opercular bones were boiled in water for some seconds, cleaned and dried before age determination (Hansen 1978).

The theoretical asymptotic lengths $\left(L_{\infty}\right)$ of perch, roach and Arctic charr were estimated by use of the von Bertallanfy growth model (von Bertalanffy 1938, Allen 1966):

$$
L_{A}=L_{\infty} \cdot(1-(\exp (-K \cdot A))) ;
$$

where $L_{A}$ is fish length (mm) at age $A$, and $K$ is Brody's growth coefficient. The length measurements and ageing used in the model were performed on fish captured in August-October, consequently fish age in the model was given as age $\mathrm{X}+0.5$, i.e. fish of age group 1 were given age 1.5 , etc. The calculations were done with the software IBM SPSS Statistics 19.

The stomach contents of each fish were conserved separately in $96 \%$ ethanol, and the prey items were later identified under a binocular microscope. In total, contents from 241 stomachs were analyzed, and the contribution of each prey item category was estimated as per cent by volume. The following prey categories were used: Chironomidae, Trichoptera, Ephmeroptera, Megaloptera, Mollusca, Cladocera, Copepoda, fish, and terrestrial insects. In roach, unspecific detritus made up a significant part of the stomach contents. Diet overlap between perch, roach and Arctic charr, and among length groups within these species, based on the composition of stomach contents, was assessed by the Schoener's (1970) similarity index:

$$
\left.D=100-0.5 \sum\left|p_{i}-q_{i}\right|\right)
$$

where $p_{i}$ and $q_{i}$ are the volume per cent of prey item $i$ in fish species or length group $p$ and $q$, respectively. $D$ ranges from $0 \%$ (no overlap) to $100 \%$ (complete overlap). D values larger than $60 \%$ are considered to indicate a significant diet overlap (Wallace 1981).

\section{Stable isotopes}

Invertebrates and fish were sampled for stable isotope $(\mathrm{C}$ and $\mathrm{N}$ ) analysis (SIA) in 2010, with some additional invertebrate samples collected 30 August 2011. Invertebrates sampled in the littoral zone included various insect larvae and snails. Zooplankton was collected with a plankton net with $90 \mu \mathrm{m}$ mesh. The zooplankton analyzed for stable isotope ratios was a mix of zooplankton, as well as selected Daphnia longispina (O.F. Müller, 1776). The invertebrates were kept alive for only a short period $(<1 \mathrm{hr})$ before frozen. Thus, the results of the analysis may have been influenced by their gut contents. As only a few samples of invertebrates were collected, the SIA data only provides a rough impression of the lake's food web. It does, however, indicate the relative trophic position of the fish species.

Tissues were prepared for stable-isotope analysis by oven drying at $60^{\circ} \mathrm{C}$, and thereafter grinded to a fine powder using an agate mortar and pestle. The ground samples were stored in acid-washed glass vials and analyzed at Institute for Energy Technology (IFE, Kjeller, Norway). Approximately $1.5 \mathrm{mg}$ of each sample was transferred to tin capsules and combusted at $1700^{\circ} \mathrm{C}$ in a Carlo Erba NCS 2500 element analyzer. $\mathrm{N}_{2}$ and $\mathrm{CO}_{2}$ were directly injected on-line to a Micromass Optima, Isotope Ratio Mass Spectrometer for determination of $\delta^{15} \mathrm{~N}$ and $\delta^{13} \mathrm{C}$. The isotope data refers to standards, Pee DEE Belemitt for carbon (Craig 1953) and atmospheric nitrogen (Mariotti 1983). The accuracy and precision of the $\delta^{13} \mathrm{C}$ and $\delta^{15} \mathrm{~N}$ analyses were checked using an internal standard (IFE trout). The $\delta^{13} \mathrm{C}$ composition of IFE trout has been calibrated against USGS-24 standard. Average values for IFE trout are: $\delta^{15} \mathrm{~N}: 11.61 \% \pm 0.26$ and $\delta^{13} \mathrm{C}:-20.21 \pm 0.26$. 


\section{RESULTS}

\section{Habitat use}

The total survey gill net catch during June-September consisted of 608 fish, completely dominated by perch and roach, and with only a few Arctic charr, burbot, and one single pike (Table 1). The CPUE was much higher in the littoral zone than in the pelagic and profundal zones. Perch and roach were the only species captured in the littoral during the summer, except the single pike (Figure 2). In the pelagic and profundal zones, CPUE was low for all species (Figure 2). During the period June-September, Arctic charr were captured in the deeper part of the pelagic (10-16 m), and in benthic gillnets in the profundal zone. Arctic charr spawning sites are at depths $0-2$ $\mathrm{m}$ in the littoral zone, and gillnetting at spawning sites in October captured Arctic charr and a few perch, burbot and minnow, in total 74 fish (Table 1). Burbot was captured solely in the profundal zone during the period June-September, but the species occurred on the spawning grounds of Arctic charr in October. European minnow were only captured during gill netting on the charr spawning grounds in October (Table 1).

\section{Size and age distribution}

The captured perch varied in length from 4.4 to $37.3 \mathrm{~cm}$, while roach lengths were from 10.1 to $33.2 \mathrm{~cm}$ (Figure 3). In the survey fishing during June-September, the captured Arctic charr were in the length-class $10-20 \mathrm{~cm}$, with mean length $( \pm$ SD) $15.7 \pm 4.9 \mathrm{~cm}$. Some larger individuals were captured on the spawning grounds in October; and the mean size of the captured spawners was $22.5 \mathrm{~cm} \pm 2.4 \mathrm{~cm}$ (Figure 3). Only small burbot, in length-class $14.5-27.8 \mathrm{~cm}$, were captured.

A total of 15 age classes of perch were represented in the catches, with a dominance of fish in age-classes $2-9$ (Figure 4). Likewise, roach was represented with many age-classes (2-13), with a dominance of age-classes 4 and $6-8$ (Figure 4). Arctic charr captured in June-September were $2-6$ years old, while fish caught on the spawning grounds were $3-6$ years old, reflecting sexual maturation from age class 3 . Burbot was represented with individuals in age-classes $2-7$, with five year old fish dominating (Figure 4).

\section{Growth patterns}

Arctic charr reached a significantly smaller asymptotic size and had a swifter stagnation in growth rate than perch and roach (Figure 5). The von Bertalanffy growth model showed a good fit for perch and roach, while the fit for Arctic charr was poorer, mainly due to a smaller age span in the length at age data, and the associated lack of data on fish in older age classes.

\section{Diet and stable isotope values}

Fish was the most common food item of perch, and even perch smaller than $10 \mathrm{~cm}$ had eaten fish (Figure 6). There was, however, some seasonal variation in diet composition. In June, perch had mainly consumed Trichoptera larvae and Ephemeroptera nymphs, although small perch $(5.0-14.9 \mathrm{~cm}$ in length) had eaten a considerable amount of crustacean zooplankton (Figure 6). In July and August, fish was the dominant food item in all length-classes of perch. Perch was the most common prey fish, but also roach had been eaten. European minnow was found in one perch stomach only. The larger perch caught in the pelagic zone seemed to be a more frequent piscivore than perch captured in the littoral and profundal zone. The summer old perch captured in October had mainly consumed cladocerans, with some additional
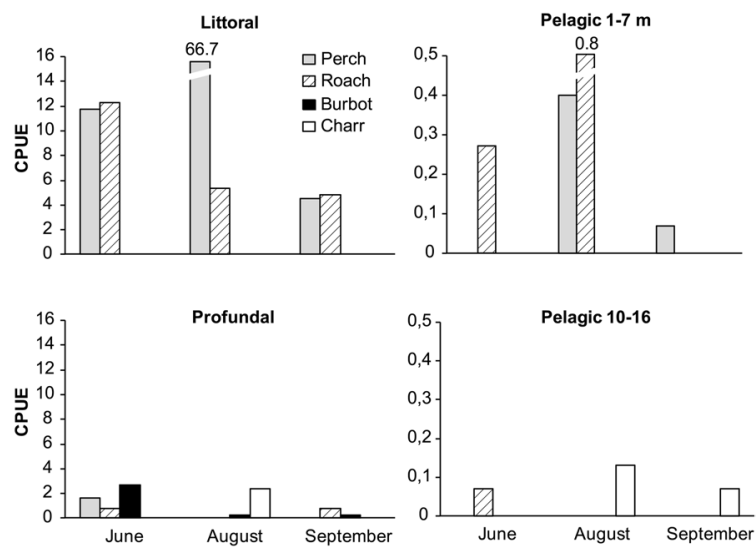

Figure 2. The habitat use of perch (Perca fluviatilis), roach (Rutilus rutilus), burbot (Lota lota) and Arctic charr (Salvelinus alpinus) in Lake Skasen as indicated by gill net catches.

Table I The number of fish caught during survey net sampling in Lake Skasen in 2010.

\begin{tabular}{lllllll}
\hline Species & June & July & Aug. & Sep. & Oct. & Total \\
\hline Perch (Perca fluviatilis) & 57 & 53 & 257 & 51 & 6 & 424 \\
Roach (Rutilus rutilus) & 60 & 8 & 23 & 43 & 0 & 134 \\
Arctic charr (Salvelinus alpinus) & 1 & 17 & 15 & 1 & 57 & 91 \\
Burbot (Lota lota) & 11 & 6 & 2 & 2 & 4 & 25 \\
Pike (Esox lucius) & 1 & 0 & 0 & 0 & 0 & 1 \\
European minnow (Phoxinus phoxinus) & 0 & 0 & 0 & 0 & 7 & 7 \\
\hline Total & 130 & 84 & 297 & 97 & 74 & 682 \\
\hline
\end{tabular}




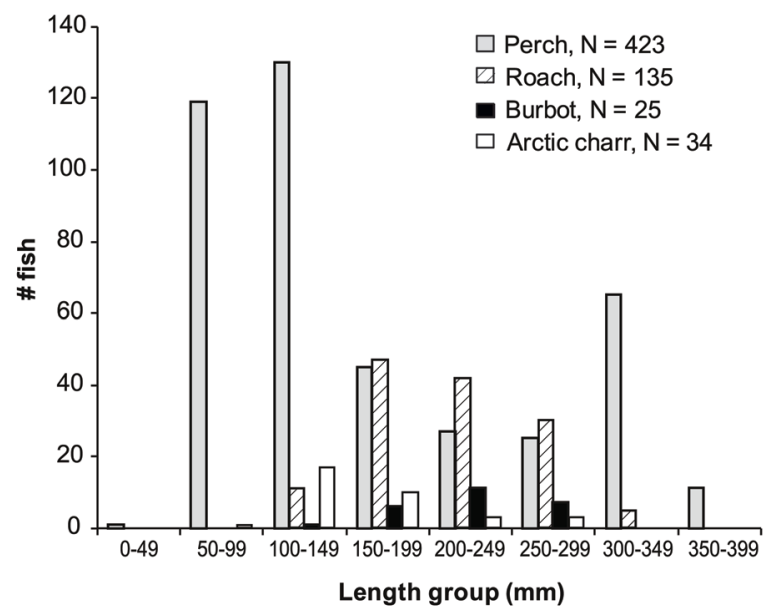

Figure 3. Length distribution of perch (Perca fluviatilis), roach (Rutilus rutilus), burbot (Lota lota) and Arctic charr (Salvelinus alpinus) in gill net catches in Lake Skasen. N is number of fish.

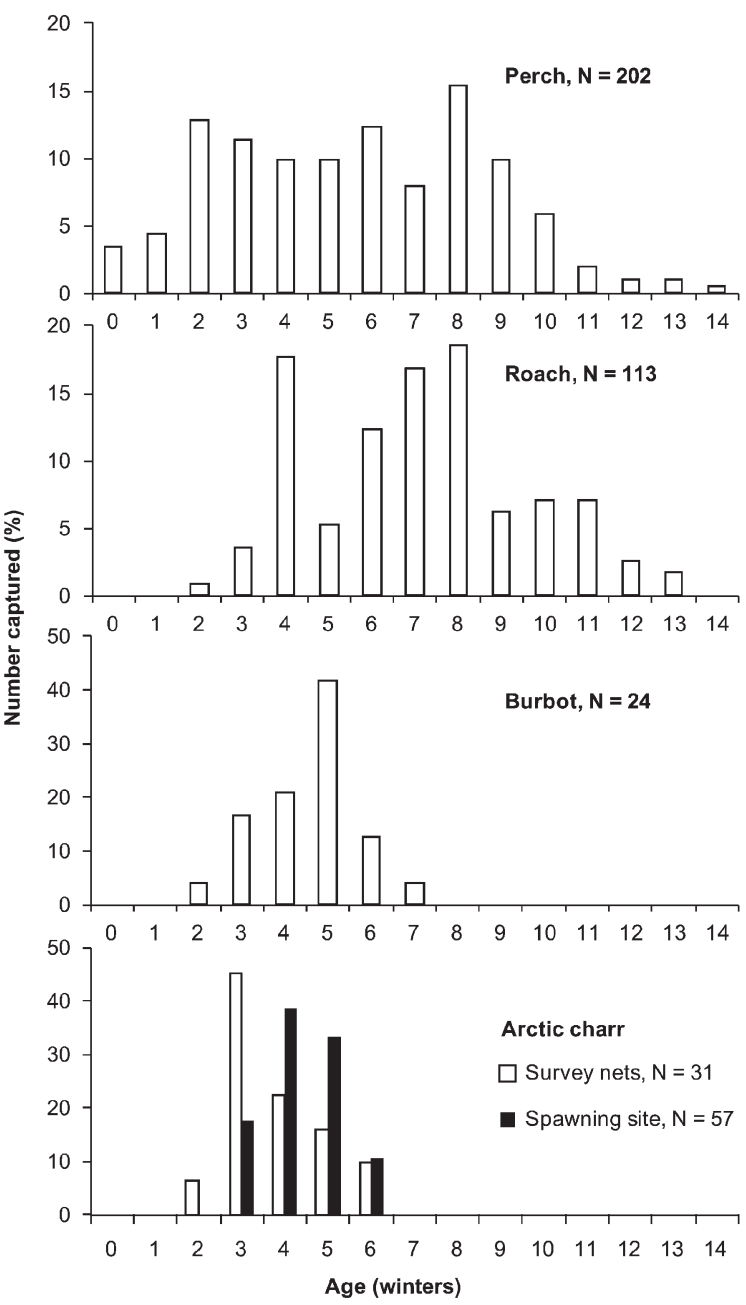

Figure 4. Age distribution of perch (Perca fluviatilis), roach (Rutilus rutilus), burbot (Lota lota) and Arctic charr (Salvelinus alpinus) in gill net catches in Lake Skasen. For Arctic charr, fish caught at the spawning grounds are also included. $\mathrm{N}$ is number of fish.

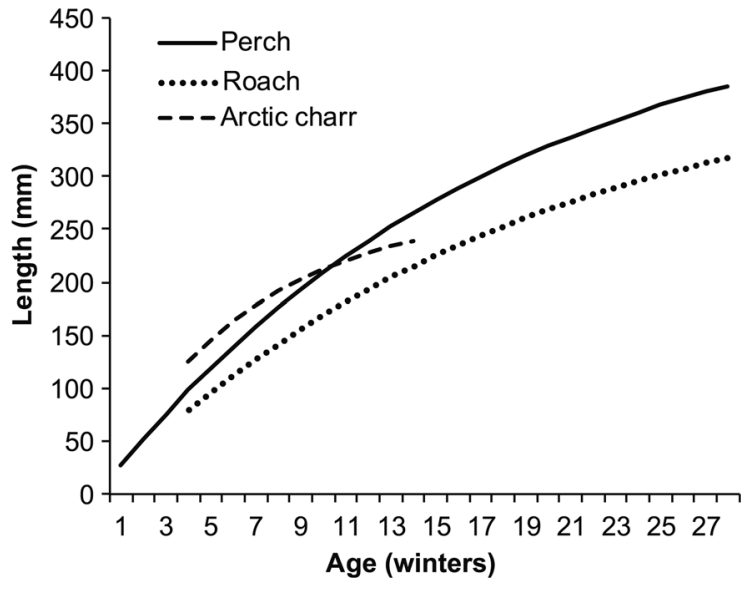

Figure 5. Growth curves for perch (Perca fluviatilis), roach (Rutilus rutilus) and Arctic charr (Salvelinus alpinus) in Lake Skasen according to the van Bertalanffy growth model. The van Bertalanffy growth parameters asymptotic length $\left(\mathrm{L}_{\infty}\right)$ and Brody's $\mathrm{K}$ were: Arctic charr: $\mathrm{L}_{\infty} \pm \mathrm{SD}=268.4 \pm 33.9 ; \mathrm{K}=0.314 \pm$ 0.091; perch: $\mathrm{L}_{\infty} \pm \mathrm{SD}=485.7 \pm 28.1 ; \mathrm{K}=0.113 \pm 0.010$; roach: $\mathrm{L}_{\infty}$ $\pm \mathrm{SD}=408.9 \pm 28.8 ; \mathrm{K}=0.107 \pm 0.012$.

Ephemeroptera nymphs and Trichoptera larvae.

The most common food items in the stomach contents of roach were terrestrial insects, Cladocera and detritus (Figure 6). Daphnia was the dominating cladoceran eaten in June, while in September, Bosmina was most common. Terrestrial insects dominated in both June and August. In length-class $20.0-33.9 \mathrm{~cm}$, Trichoptera larvae and Ephemeroptera nymphs were relatively common.

Cladocera, including Bythotrephes longimanus (Leydig, 1860), Daphnia spp. and Bosmina spp., were the most common food items of Arctic charr throughout summer (Figure 7). Small perch and roach made up a considerable part of the diet of Arctic charr in length-class $15.0-26.0 \mathrm{~cm}$. For small Arctic charr, in length-class $9.0-14.9 \mathrm{~cm}$, Bosmina and Daphnia were most important. Chironomid larvae and pupae, as well as Ephemeroptera nymphs were also eaten by charr, although their contribution to the total diet was low. Charr sampled at the spawning grounds in the littoral area in October had also eaten some terrestrial insects and copepods, and one stomach contained charr eggs.

The stomach contents of burbot mainly consisted of Ephemeroptera nymphs, chironomid larvae and pupae, and Pisidium sp. In October, Sialis larvae were found in addition to nymphs of Ephemeroptera and chironomid larvae. Neither Arctic charr eggs nor fish were detected in the stomachs of the burbot caught on the spawning grounds of charr in October.

The stable isotope analysis revealed a restricted trophic niche of Arctic charr relative to the other fish species (Figure 8). In terms of $\delta^{13} \mathrm{C}$ signatures, Arctic charr showed low variation among individuals, with all fish positioned towards the extreme pelagic/profundal end of the littoral-pelagic 


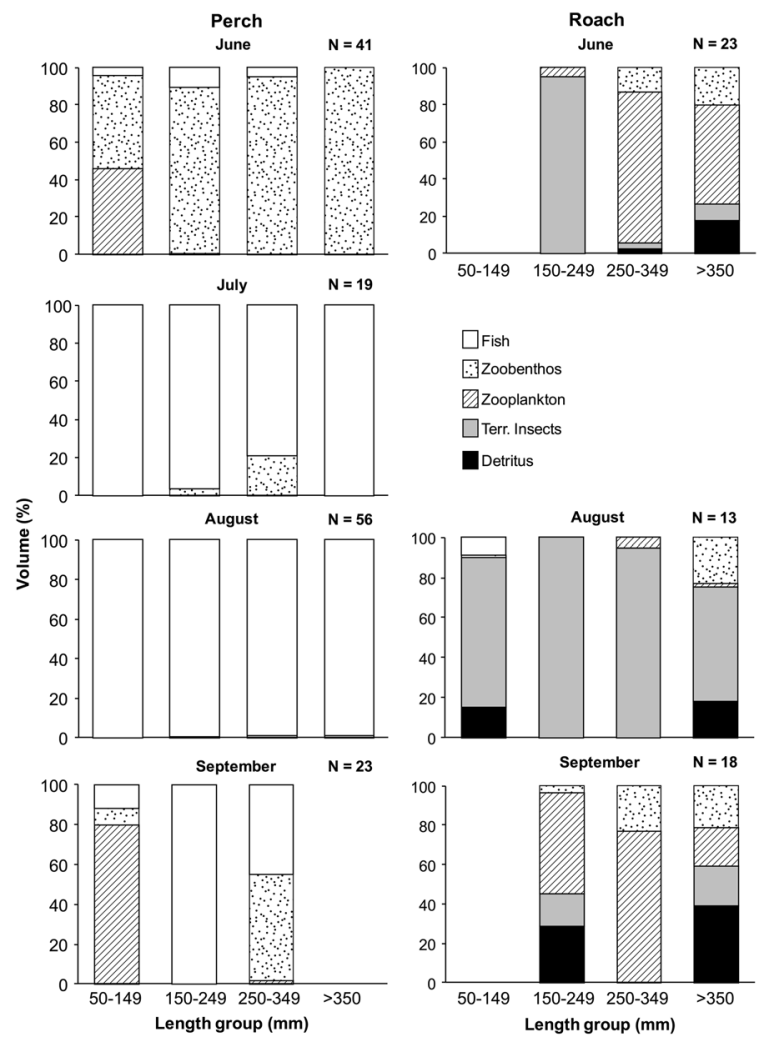

Figure 6. Stomach contents composition, in volume per cent, of four size groups of perch (Perca fluviatilis) and roach (Rutilus rutilus) captured in Lake Skasen. N is number of samples analyzed.

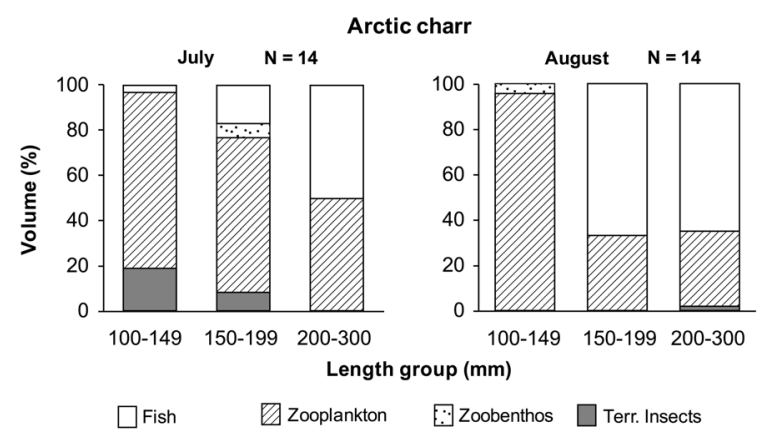

Figure 7. Stomach contents composition, in volume per cent, of Arctic charr (Salvelinus alpinus), captured in Lake Skasen. N is number of samples analyzed.

continuum. There was only a very slight overlap with perch and burbot in $\delta^{13} \mathrm{C}$ signature, but both these species exhibited large individual variation along the littoral-pelagic continuum, reflecting that perch and burbot find food in the littoral as well as the pelagic and/or profundal habitats. Roach and minnow showed less individual variation in $\delta^{13} \mathrm{C}$ signatures, but while roach was positioned entirely within the variation of perch, minnow was positioned towards the extreme littoral end of the continuum. Perch exhibited the largest individual variation also in $\delta^{15} \mathrm{~N}$ signature, with Arctic charr, roach and burbot showing intermediate individual variation. In terms of $\delta^{15} \mathrm{~N}$ signatures, the differences between the fish species were small. Mean $\delta^{15} \mathrm{~N} \pm \mathrm{SD}$ (in \%) was highest in Arctic charr (6.2 \pm 0.3 ), only slightly lower in perch $(6.0 \pm 0.7)$, burbot $(5.9 \pm 0.5)$, and roach $(5.8 \pm 0.3)$, and the lowest $\delta^{15} \mathrm{~N}$ values were seen in minnow (5.6 $\pm 0.3)$. Perch exhibited a significant increase in $\delta^{15} \mathrm{~N}$ signature with increasing body length $(\mathrm{L}, \mathrm{mm}):\left(\delta^{15} \mathrm{~N}=0.006 \cdot \mathrm{L}+4.85\right.$, $\left.\mathrm{R}^{2}=0.64, \mathrm{p}<0.001\right)$. The mean $\delta^{15} \mathrm{~N}$ signatures $( \pm \mathrm{SD})$ of perch smaller than $100 \mathrm{~mm}(5.7 \pm 0.7, \mathrm{~N}=5)$, and larger than 300 $\mathrm{mm}(7.1 \pm 0.1, \mathrm{~N}=3)$, were significantly different (t-test, 6 d.f., $\mathrm{P}=0.011)$. Age- 0 roach and age- 0 pike collected by dip net in August had $\delta^{15} \mathrm{~N}$ signatures at 2.6 - 2.7 (Figure 8), which is about one trophic level $(\sim 3.2 \%)$ below perch.

A significant diet overlap (Schoener's D $>60 \%$ ) was found among various size classes of perch in all sampling periods. In August, the three length classes of perch $(50-149 \mathrm{~mm}, 150$ $249 \mathrm{~mm}$ and $250-340 \mathrm{~mm}$ ) had nearly identical diets, with $\mathrm{D} \geq 99 \%$. In August and September roach length classes 100 - $199 \mathrm{~mm}$ and 200-340 $\mathrm{mm}$ had significant diet overlap (D = $77-83 \%)$. The remaining pairwise comparisons, both between species and between length groups within species showed no significant diet overlaps $(\mathrm{D} \leq 60 \%)$.

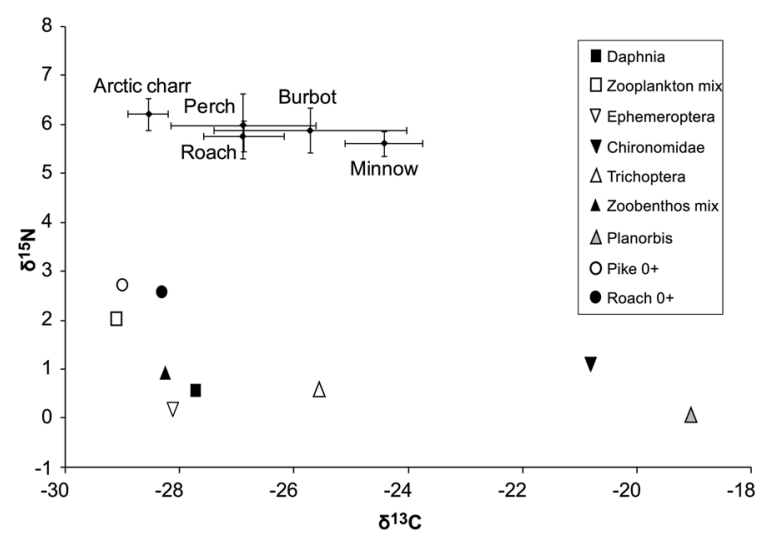

Figure 8. Biplot of stable isotope ratios of nitrogen $\left(\delta^{15} \mathrm{~N}\right)$ and carbon $\left(\delta^{13} \mathrm{C}\right)$ in fish and invertebrates from Lake Skasen. Vertical and horizontal lines for fish indicate standard deviation.

\section{DISCUSSION}

The observed gill net catches in the littoral, profundal and pelagic zone of Lake Skasen during the period June-September 2010, demonstrated a distinct segregation of the fish species according to habitat and the associated water temperatures. Arctic charr and burbot were captured solely in cold water in the profundal and deep pelagic, while perch and roach were captured in the littoral and upper pelagic, where water was warmer, but still relatively cool five meters below the surface. Both roach and perch were most active during the summer, as indicated by substantial increases in gill net catches. This is 
also observed in other lakes with these species (Brabrand \& Borgstrøm 2000; van Dijk et al. 2002; Linløkken \& Haugen 2006). Burbot and Arctic charr, on the other hand, often staying in deeper water with lower temperatures (Hofmann \& Fischer 2002; Klemetsen et al. 2003), may have a lower catchability by gillnetting, and thereby a lower CPUE due to low temperatures (Borgstrøm 2000). However, the dominant role of perch in the gill net catches can hardly be due to differences in catchability alone, but is probably a result of a very high population density of perch compared to the other species in Lake Skasen. Comparing gill net CPUE from different lakes at different times, and obtained with slightly different survey nets, should be done with utmost care, as CPUE may only provide a rough indication of fish population densities in the various lakes. However, Sandlund et al. (2010) studied Arctic charr and whitefish in five lakes in eastern Norway, with gill netting in all habitat types, and in all the lakes, the CPUE of Arctic charr was higher than what was obtained in Lake Skasen. This may support the impression that the Arctic charr population in Skasen is at a very low level. According to the CPUE values, the population density of burbot in Lake Skasen also seems to be low when compared to the CPUE for this species in for example Lake Mjøsa (Sandlund et al. 1985).

The low population density of Arctic charr in Lake Skasen could be a result of low spawning success, caused by unfavourable $\mathrm{pH}$ and high silting rates on the spawning beds. However, the $\mathrm{pH}$ of the lake water has probably never been at a level causing serious problems for Arctic charr (cf. Hesthagen \& Sandlund 1995). As water quality has been good also in terms of nutrient contents (Løvik 2001), it is unlikely that low recruitment success is due to poor water quality. We have no data to show sedimentation rates at the spawning sites, but one may speculate that this is a potential problem for all Arctic charr populations in humic waters.

Several authors report that climate warming may cause the decline of Arctic charr stocks (Winfield et al. 2010, Jeppesen et al. 2012). In the Lake Skasen area, meteorological data indicate that summer air temperatures (June-August) have been stable over the last seven decades. It is therefore reasonable to assume that temperature conditions in the lake water may also have been relatively stable. However, the present temperature regime in Lake Skasen may not be favourable for Arctic charr, as surface waters were above $16^{\circ} \mathrm{C}$ for several weeks in the summer of 2010. Even though Arctic charr commonly utilize both the littoral zone and the upper part of the pelagic zone when living in allopatry, or in sympatry with low densities of other species, (Langeland et al. 1991; Langeland \& L'AbéeLund 1996; Klemetsen et al. 2002), it has also been shown that high water temperatures may moderate this habitat use. The species seems to avoid habitats with temperatures above $16^{\circ} \mathrm{C}$, and prefer to reside in cooler, deeper waters (Langeland \& L'Abee-Lund 1998). Even in June, however, while water temperatures were low, no Arctic charr were captured in the littoral or the upper pelagic habitats of Lake Skasen. This may indicate interactive segregation between Arctic charr and roach/ perch (cf. Nilsson 1967). With the documented presence of large perch, it may also reflect predator avoidance.

The low Arctic charr population density in combination with low individual growth rate may indicate other factors stressing the population. Arctic charr in Lake Skasen are restricted to the energetically least profitable habitats, giving low individual growth rate. High predation risk in the most favorable habitats (i.e. the littoral zone) may prevent Arctic charr from exploiting the better food resources in these habitats. However, the fact that Arctic charr to some extent did prey on small perch and roach indicates that charr did move into shallower water for feeding, or that there is a habitat overlap between prey (small perch and roach) and predator (Arctic charr) at intermediate depths. In a survey of fish populations in five lakes in the UK, situated from 21 to $486 \mathrm{~m}$ a. s. 1., Arctic charr was dominant in three lakes where perch and cyprinids were absent, common in one lake with brown trout and perch, while very rare in the fifth lake, where whitefish dominated (Winfield et al. 2009). Similarly, a decline in Arctic charr populations caused by competition from introduced whitefish has frequently been documented from Norway and Sweden (Svärdson 1976; Sandlund et al. 2010, 2013). In Lake Sølensjøen, where Arctic charr was close to extinction due to competition from the introduced whitefish population, substantially increased exploitation of whitefish was accompanied by a significant increase in the Arctic charr population (Museth et al. 2007). This was interpreted as an effect of reduced competition from whitefish. In Lake Skasen, however, perch may be the key regulatory species due to its piscivory from a very small size.

Both roach and perch commonly form stunted populations in forest lakes, due to excessive recruitment (Linløkken et al. 2008). There is no indication of stunting in either of these species in Lake Skasen, indicating that there is restricted recruitment. Perch and roach are distinct food competitors (Persson \& Greenberg 1990; Brabrand 2000), but different from roach, perch may also be a predominant predator on fish, including roach (Eklöv \& Persson 1995). In Lake Skasen, fish were found as food items in perch as small as $9 \mathrm{~cm}$. The prey species in these cases was not identified, but dense schools of cyprinid fry were observed in the littoral zone of the lake during summer. These age- 0 fish were probably easily available prey for small perch. We do not have stable isotope values for perch smaller than $82 \mathrm{~mm}$, but roach fry $(\sim 40 \mathrm{~mm})$ sampled in the littoral zone had a $\delta^{15} \mathrm{~N}$ value at 2.6\%, which is about one trophic level (i.e., $~ 3.2 \%$ ) below perch. Larger perch had both perch and roach in their stomachs, with perch as the most common prey fish. The significant difference in $\delta^{15} \mathrm{~N}$ signatures between small $(82-97 \mathrm{~mm})$ and large $(>300 \mathrm{~mm})$ perch supports the direct observations of large perch being frequent piscivores, and also feeding on their smaller conspecifics. Roach was also common in perch stomachs in Lake Skasen. In roach from gill net catches (body lengths $137-290 \mathrm{~mm}$ ), the mean $\delta^{15} \mathrm{~N}$ value was similar to small perch, i.e. approximately 
$1.4 \%$ below large perch. Perch around $300 \mathrm{~mm}$ are able to prey on roach with lengths at least up to around $170 \mathrm{~mm}$ (Borgstrom \& Eie 1984). It is likely that a $300 \mathrm{~mm}$ perch may be able to prey on even larger Arctic charr, which normally has a more slender body shape. Since perch in length-class $25-35 \mathrm{~cm}$ constituted a relatively high proportion of the catch, the diet analysis indicate that predation by perch may constitute a considerable mortality risk to a wide range of age groups of the other fish species as well as their own young in this community. Heavy predation impact from perch has also been documented from other fish communities (Craig 1978; Persson \& Greenberg 1990; Tonn et al. 1992, Jacobsen et al. 2002).

A low fishing pressure on perch may result in high adult survival. Together with good access to prey fish this may result in many perch reaching a large body size, and consequently a high predation pressure on all fish species sharing habitat with perch. Accordingly, due to a high predation risk in the littoral area, potential prey fish may seek to other habitats, i. e. either the pelagic or the profundal. The occurrence of perch and roach in Arctic charr stomachs indicates that this does happen. The upper part of the pelagic habitat may be a profitable habitat for zooplanktivores like roach, small perch and Arctic charr, but as we observed in Lake Skasen, larger perch may also use this habitat. Roach and perch typically reside in the littoral zone or close to the surface in the pelagic, sharing habitats with the piscivorous perch. On the other hand, Arctic charr remains in deeper waters where it may find a refuge from predators and competitors, but where there is low food availability and low temperatures (around $7^{\circ} \mathrm{C}$ ) far below the optimum for growth of Arctic charr, which seems to be at temperatures around $15^{\circ} \mathrm{C}$ (Larsson \& Berglund 1998, 2005). However, the species seems to select a lower temperature than what is optimal for its growth, probably because it is optimizing its growth efficiency instead of its growth rate (Berglund 2005), and this may explain the low annual growth rate of charr in Lake Skasen. The growth efficiency at low temperatures is likely the basis for the improved competitive abilities of Arctic charr in colder waters and during periods with ice cover (Finstad et al. 2011, Helland et al. 2011, Ulvan et al. 2011).

Roach may be a key species due to its effective zooplankton predation (Persson 1983; Winfield 1986, Winfield et al. 2008), and theoretically food competition with roach may have forced Arctic charr to leave the most profitable feeding habitats, with the profundal zone as the only refuge remaining. However, since $B$. longimanus was present in the diet of Arctic charr, this may suggest that the zooplankton prey resource for charr is not down-grazed and limited. Small roach and perch in the diet of Arctic charr indicate that movements to the pelagic or littoral areas may take place, but still the narrow trophic niche of Arctic charr revealed by the analysis of stable nitrogen and carbon isotope ratios, suggests the confined existence of Arctic charr in the profundal and deep pelagic zone, where available food resources mainly are based on biomass produced in the pelagic zone (cf. Johnsen et al. 2012). The higher mean $\delta^{15} \mathrm{~N}$ value of
Arctic charr than the other fish species (except large perch), but with lower $\delta^{13} \mathrm{C}$ values compared to perch and roach, may indicate that Arctic charr also feed on its conspecifics, most probably in the period after hatching, since no specimens were found in the summer and autumn diet. It is somewhat surprising that burbot, normally being a predator, do not have higher $\delta^{15} \mathrm{~N}$ signatures than small perch, Arctic charr, and roach. The analysed burbot specimen were however, relatively small $(\sim 150$ $250 \mathrm{~mm}$ ), indicating that they might still have been feeding only on profundal invertebrates.

The analysis of stable $\mathrm{N}$ - and $\mathrm{C}$-isotopes in fish tissue from Lake Skasen indicates a high degree of overlap between perch, roach and burbot. The diet overlap estimated by Schoener's D based on analysis of stomach contents seems to differ, and does not indicate any significant diet overlap between these fish species. This is not surprising, as these two methods have a completely different basis. The $\delta^{13} \mathrm{C}$ values in fish muscle indicate in which habitat the individual fish has found its prey over the last 2-3 months, with a gradient from the littoral (high $\delta^{13} \mathrm{C}$ values) to the pelagic/profundal (low $\delta^{13} \mathrm{C}$ values). $\delta^{15} \mathrm{~N}$ values indicate the trophic level of the prey eaten over the same period (i.e. primary consumers, secondary consumers, predators). Diet analysis, on the other hand, focuses on the taxonomy of the prey items. Thus, for instance, chironomid larvae in the littoral zone and in the profundal zone have very different $\delta^{13} \mathrm{C}$ signatures which will be reflected in the $\delta^{13} \mathrm{C}$ signatures of the fish eating them. In diet analysis, chironomid larvae will normally be pooled regardless of where the fish has eaten them.

A negative correlation has been documented between mean adult size and population density in Arctic charr populations, such as the planktivorous Arctic charr ("murta") in Lake Thingvallavatn, Iceland (Snorrason et al. 1992), in Loch Doon in Scotland (Maitland et al. 1991), and Lake Takvatn in Norway (Klemetsen et al. 2002). Apparently, the population density of Arctic charr in Lake Skasen is very low, but still catch data from one particular spawning site indicate that the mean body weight of spawners have decreased from approximately $218 \mathrm{~g}$ in 1992 - 1996 to $91 \mathrm{~g}$ in 2006 - 2007 (J. Gressberg, pers. comm., O.T. Sandlund, unpublished data), probably demonstrating that the population is squeezed due to interactions with other species. With the confined use of the profundal habitat of Arctic charr in Lake Skasen, intraspecific interactions may be important for the population dynamics, as observed in Lake Lønavatn, Western Norway (Jonsson \& Østli 1979). In a situation where all age-classes stay in the profundal habitat, as seems to be the case in Lake Skasen, competition in combination with intraspecific predation, may similarly lead to low juvenile survival, and result in an overall low population density. Since the potential piscivore, burbot, does occur in the same profundal habitat, this species may additionally contribute as a negative factor for Arctic charr abundance. The general decline in European Arctic charr populations during the last decades seems to be related to an increase in summer temperatures (Jeppesen et al. 2012), 
which could likely be a result of increased predation pressures from species favoured by increased temperatures. In Lake Ellioavatn in Iceland, where Arctic charr have declined during a period with increased temperatures, a parallel increase in charr length at age was observed (Jeppesen et al. 2012), and the decline in numbers may thus be related to increased predation on young charr, both by Arctic charr and brown trout.

In conclusion, decreasing fishing pressures in shallow and medium deep lakes with complex fish communities may have been important factors for the decline of Arctic charr populations. With high densities of large perch as well as roach in the upper pelagic and in the littoral habitat of Lake Skasen, Arctic charr seem to be confined to a refuge in the profundal and deep pelagic parts of the lake. This may be reinforced by the relatively high water temperatures in shallow waters and in the upper part of the pelagic zone of the lake, although there is no general trend towards warmer summers in this region. Co-existence of all size- and age-classes of Arctic charr in the relatively un-productive deep habitats, may furthermore result in intraspecific interactions, which severely reduce the population density. To counteract this negative condition for the squeezed Arctic charr population in Lake Skasen, as well as in corresponding lakes, may thus be to introduce a high fishing pressure on competitor and predatory species like roach and perch. The alternative may be local extinctions of these marginal populations, and consequently a shrinking area of occurrence of Arctic charr.

\section{ACKNOWLEDGMENTS}

Our thanks are due to Arnfinn Skogrand and Jan Torgersrud for assistance during field work. Jo Gressberg provided Arctic charr caught during spawning, as well as information on Lake Skasen fisheries. The fishing rights owners' association, Skasen fiskeforening, is thanked for their supportive interest in the project. The County Governor of Hedmark provided economic support to the project. Additional economic support was received from Norwegian Institute for Nature Research (NINA) and Norwegian University of Life Sciences (UMB). Kari Sivertsen, NINA, assisted in producing the figures.

\section{REFERENCES}

Allen KR. 1966. A method of fitting growth curves of the von Bertalanffy type to observed data. Journal of the Fisheries Research Board of Canada 23: 163-179.

Borgstrøm R, Eie JA. 1984. Undersøkelse av fisk, zooplankton og bunndyr i Årungen. Sluttrapport 538, 16 pp. Norges Landbruksvitenskapelige Forskningsråd (NLVF), Oslo.

Brabrand Å. 2000. Komplekse fiskesamfunn med dominans av karpefisk, abborfisk og gjedde. In: Borgstrøm R, Hansen LP (eds). Fisk i ferskvann. Landbruksforlaget, Oslo, pp 130-144.
(In Norwegian)

Brabrand $\AA$, Borgstrøm R. 2000. Fiskesamfunn og miljø. In: Borgstrøm R, Hansen LP (eds). Fisk i ferskvann. Landbruksforlaget, Oslo, pp 66-73. (In Norwegian)

Brabrand A, Faafeng BA. 1993. Habitat shift in roach (Rutilus rutilus) induced by pikeperch (Stizostedion lucioperca) introduction: predation risk versus pelagic behaviour. Oecologia 95: 38-46.

Brabrand Å, Saltveit SJ. 1983. Fiskeribiologiske studier i Skasenvassdraget, Hedmark. Rapport, Laboratorium for ferskvannsøkologi og innlandsfiske 62: 1-62. (In Norwegian)

Christensen JM. 1964. Burning of otoliths, a technique for age determination of soles and other fish. Journal du Conseil Conseil International pour l'Exploration de la Mer 26: 73-81.

Craig, H. 1953. The geochemistry of stable isotopes. Geochimica et Cosmochimica Acta 3: 53-93.

Craig JF. 1978. A study of the food and feeding of perch, Perca fluviatilis L., in Windermere. Freshwater Biology 8: 59-68.

Dahl K. 1917. Studier og forsøk over ørret og ørretvann. Centraltrykkeriet, Kristiania. (In Norwegian)

Dickson W, Hörnström E, Ekström C, Almer B. 1975. Rödingsjöar söder om Dalälven. Information från Sötvattenslaboratoriet, Drottningholm 7, 140 pp. (In Swedish)

Eklöv P, Persson L. 1995. Species-specific antipredator capacities and prey refuges: interactions between piscivorous perch (Perca fluviatilis) and juvenile perch and roach (Rutilus rutilus). Behavioral Ecology and Sociobiology 37: 169-178.

Finstad A G, Forseth T, Jonsson B, Bellier E, Hesthagen T, Jensen A, Hessen DO, Foldvik A. 2011. Competitive exclusion along climate gradients: energy efficiency influences the distribution of two salmonid fishes. Global Change Biology 17: 1703-1711.

Hansen LP. 1978. Age determination of roach, Rutilus rutilus (L.), from scales and opercular bones. Archiw für Fischereiwissenschaft 29: 93-98.

Helland IP, Finstad AG, Forseth T, Hesthagen T, Ugedal O. 2011. Ice-cover effects on competitive interactions between two fish species. Journal of Animal Ecology 80: 539-547.

Hesthagen T, Sandlund OT. 1995. Current status and distribution of Arctic char, Salvelinus alpinus (L.), in Norway: The effects of acidification and introductions. Nordic Journal of Freshwater Research 71: 275-295.

Hofmann N, Fischer P. 2002. Temperature preferences and critical thermal limits of burbot: Implications for habitat selection and ontogenetic habitat shift. Transactions of the American Fisheries Society 131: 1164-1172.

Huitfeldt-Kaas H. 1918. Ferskvandsfiskenes utbredelse og indvandring i Norge med et tillæg om krebsen. Centraltrykkeriet, Kristiania (Oslo). $119+35$ pp. (In Norwegian)

Jacobsen L, Berg S, Broberg M, Jepsen N, Skov C. 2002. Activity and food choice of piscivorous perch (Perca fluviatilis) in a eutrophic shallow lake: a radio-telemetry study. Freshwater Biology 47: 2370-2379.

Jeppesen E, Mehner T, Winfield IJ, Kangur K, Sarvala J, Gerdeaux D, Rask M, Malmquist HJ, Holmgren K, Volta P, Romo S, Eckmann R, Sandström A, Blanco S, Kangur A, Stabo HR, Tarvainen M, Ventelä A-M, Søndergaard M, Lauridsen TL, Meerhoff M. 2012. Impacts of climate warming on the longterm dynamics of key fish species in 24 European lakes. Hydrobiologia 694: 1-39. 
Johnsen SI, Sandlund OT, Dokk JG, Museth J, Rognerud S, Gjelland KØ, Helland IP. 2012. Fiskesamfunnet i Aursunden, Røros kommune. NINA Report 864: 1-49. (In Norwegian)

Johnson L. 1976. Ecology of Arctic populations of lake trout, Salvelinus namaycush, lake whitefish, Coregonus clupeaformis, Arctic char, S. alpinus, and associated species in unexploited lakes of the Canadian Northwest Territories. Journal of the Fisheries Research Board of Canada 33: 2459-2488.

Jonsson B, Østli T. 1979. Demographic strategy in char compared with brown trout in Lake Løne, Western Norway. Report Institute for Freshwater Research, Drottningholm 58: 45-54.

Klemetsen A, Amundsen, P-A, Grotnes PE, Knudsen R, Kristoffersen R, Svenning M-A. 2002. Takvatn through 20 years: long-term effects of an experimental mass removal of Arctic charr, Salvelinus alpinus, from a subarctic lake. Environmental Biology of Fishes 64: 39-47.

Klemetsen A, Amundsen PA, Dempson JB, Jonsson B, Jonsson N, O'Connell MF, Mortensen E. 2003. Atlantic salmon (Salmo salar L.), brown trout (Salmo trutta L.) and Arctic charr (Salvelinus alpinus L.): a review of aspects of their life histories. Ecology of Freshwater Fish 12: 1-59.

Knudsen R, Amundsen P-A, Klemetsen A. 2010. Arctic charr in sympatry with burbot: ecological and evolutionary consequences. Hydrobiologia 650: 43-54.

Langeland A, L'Abée-Lund JH, Jonsson B, Jonsson N. 1991. Resource partitioning and niche shift in Arctic charr Salvelinus alpinus and brown trout Salmo trutta. Journal of Animal Ecology 60: 895-912.

Langeland A, L’Abée-Lund JH, Jonsson B. 1995. Ørret- og røyesamfunn - habitatbruk og konkurranse. In: Borgstrøm R, Jonsson B, L'Abée-Lund JH (eds). Ferskvannsfisk. Økologi, kultivering og utnytting. Norwegian Research Council, Oslo. pp 35-43. (In Norwegian)

Langeland A, L'Abée-Lund JH. 1996. Habitat use, size and age structure in sympatric brown trout (Salmo trutta) and Arctic charr (Salvelinus alpinus) stocks: resistance of populations to change following harvest. Ecology of Freshwater Fish 5: 49-58.

Langeland A, L'Abée-Lund JH. 1998. An experimental test of the genetic component of the ontogenetic habitat shift in Arctic charr (Salvelinus alpinus). Ecology of Freshwater Fish 7: 200207.

Larsson, S. 2005. Thermal preference of Arctic charr, Salvelinus alpinus, and brown trout, Salmo trutta - implications for their niche segregation. Environmental Biology of Fishes 73: 89-96.

Larsson S, Berglund I. 1998. Growth and food consumption of $0+$ Arctic charr fed pelleted or natural food at six different temperatures. Journal of Fish Biology. 52: 230-242.

Larsson S, Berglund I. 2005. The effect of temperature on the energetic growth efficiency of Arctic charr (Salvelinus alpinus L.) from four Swedish populations. Journal of Thermal Biology 30: $29-36$

Linløkken A, Haugen TO. 2006. Density and temperature dependence of gill net catch per unit effort for perch, Perca fluviatilis, and roach, Rutilus rutilus. Fisheries Management and Ecology 13: 61-269.

Linløkken A, Bergman E, Greenberg L, Holt Seeland PA. 2008. Environmental correlates of population variables of perch (Perca fluviatilis) in boreal lakes. Environmental Biology of Fishes 82: 401-408.
Løvik, JE. 2001. Miljøtilstanden i innsjøer og vassdrag i Hedmark ved årtusenskiftet. NIVA rapport O-20204-4336, 39 pp. (In Norwegian with English summary).

Mariotti, A. 1983. Atmospheric nitrogen is a reliable standard for natural abundance ${ }^{15} \mathrm{~N}$ measurements. Nature 303: 685-687.

Maitland PS, May L, Jones DH, Doughty CR. 1991. Ecology and conservation of Arctic charr, Salvelinus alpinus (L.), in Loch Doon, an acidifying loch in southwest Scotland. Biological Conservation 55: 167-197.

Moen G. 1963. Skasen: en limnologisk undersøkelse. Master thesis in geography, University of Oslo. 117 pp. (In Norwegian).

Museth J, Sandlund OT, Borgstrøm R. 2007. Coexistence between introduced whitefish (Coregonus lavaretus) and native Arctic charr (Salvelinus alpinus) depends on heavy whitefish exploitation. Advances in Limnology 60: 343-350.

Nilsson NA. 1967. Interactive segregation between fish species. In: Gerking SD (ed.) The biological basis of freshwater fish production. Blackwell, Oxford. Pp 295-313.

Nysæther JK. 1977. Fisket i Osensjøen. In: Fossum T. (ed.) Årbok for Norsk Skogbruksmuseum, Nr 8 - 1976-77. Elverum. Pp 249267. (In Norwegian)

Persson L. 1983. Effects of intra- and interspecific competition on dynamics and size structure of a perch, Perca fluviatilis, and a roach, Rutilus rutilus, population. Oikos 41: 126-132.

Persson L, Greenberg LA. 1990. Juvenile competitive bottlenecks: The perch (Perca fluviatilis)-roach (Rutilus rutilus) interaction. Ecology 71: 44-56.

Pethon P. 2005. Aschehougs store fiskebok. Revised edition. Aschehoug, Oslo. 468 pp. (In Norwegian)

Power G. 1978. Fish population structure in arctic lakes. Journal of the Fisheries Research Board of Canada 35: 53-59.

Rognerud S. 1985. Limnologisk undersøkelse i seks innsjøer i Hedmark fylke sommeren 1985. NIVA Report O-84126, 18 +12 pp. Norwegian Institute for Water Research, Oslo (In Norwegian)

Sandlund OT, Hesthagen T, Brabrand A. 2013. Coregonid introductions in Norway: well-intended and successful, but destructive. Advances in Limnology 64: 345-358.

Sandlund OT, Klyve L, Næsje TF. 1985a. Growth, habitat and food of burbot Lota lota in Lake Mjøsa. Fauna 38: 37-43. (In Norwegian, English summary)

Sandlund OT, Museth J, Næsje TF, Rognerud S, Saksgård R, Hesthagen T, Borgstrøm R. 2010. Habitat use and diet of sympatric Arctic charr (Salvelinus alpinus) and whitefish (Coregonus lavaretus) in five lakes in southern Norway: not only interspecific population dominance? Hydrobiologia 650: 27-41.

Schoener TW. 1970. Nonsynchronous spatial overlap of lizards in patchy habitats. Ecology 51: 408-418.

SLU 2012. Sydliga randbestånd av röding. http://www.slu.se/sv/ fakulteter/nl-fakulteten/om-fakulteten/institutioner/akvatiskaresurser/radgivning/hotade-arter/sydliga-randbestand-avroding/ Sveriges Lantbruksuniversitet (accessed 19.05.2013). (In Swedish).

Snorrason SS, Jónasson PM, Jonsson B, Lindem T, Malmquist HJ, Sandlund OT, Skúlason S. 1992. Population dynamics of the planktivorous arctic charr Salvelinus alpinus ("murta") in Thingvallavatn. Oikos 64: 352-364.

Svärdson G. 1976. Interspecific population dominance in fish 
communities of Scandinavian lakes. Report Institute for Freshwater Research, Drottningholm 55: 144-171.

Tonn WM, Paszkowski CA, Holopainen IJ. 1992. Piscivory and recruitment - mechanisms structuring prey populations in small lakes. Ecology 73: 951-958.

Ulvan EM, Finstad AG, Ugedal O, Berg OK. 2011. Direct and indirect climatic drivers of biotic interactions: ice-cover and carbon runoff shaping Arctic char Salvelinus alpinus and brown trout Salmo trutta competitive asymmetries. Oecologia 168: 277-287.

von Bertalanffy L. 1938. A quantitative theory of organic growth. Human Biology 10: 181-213.

van Dijk PLM, Staaks G, Hardewig I. 2002. The effect of fasting and refeeding on temperature preference, activity and growth of roach, Rutilus rutilus. Oecologia 130: 496-504.

Wallace RK. 1981. An assessment of diet overlap indices. Transactions of the American Fisheries Society 110: 72-76.

Winfield IJ. 1986. The influence of simulated aquatic macrophytes on the zooplankton consumption rate of juvenile roach, Rutilus rutilus, rudd, Scardinius erythrophthalmus, and perch, Perca fluviatilis. Journal of Fish Biology 29: 37-48.

Winfield IJ, Fletcher JM, James JB. 2008. The Arctic charr (Salvelinus alpinus) populations of Windermere, UK: population trends associated with eutrophication, climate change and increased abundance of roach (Rutilus rutilus). Environmental Biology of Fishes 83: 25-35.

Winfield IJ, Fletcher JM, James JB, Bean CW. 2009. Assessment of fish populations in still waters using hydroacoustics and survey gill netting: Experiences with Arctic charr (Salvelinus alpinus) in the UK. Fisheries Research 96: 30-38.

Winfield IJ, Hateley J, Fletcher JM, James JB, Bean CW, Clabburn P. 2010. Population trends of Arctic charr (Salvelinus alpinus) in the UK: assessing the evidence for a widespread decline in response to climate change. Hydrobiologia 650: 55-65.

Editorial responsibility: Jan Davidsen.

This article is open-access and distributed under the terms of the Creative Commons Attribution-Noncommercial 3.0 Unported License (http://creativecommons.org/licenses/by-nc/3.0/). This permits all non-commercial use, distribution, and reproduction in any medium, provided the original work is properly cited. 